\title{
Evaluation of the Impacts of Climate Change on Runoff in Dadu River Basin Based on CORDEX Regional Climate Model
}

\author{
Zhangrong $\operatorname{Pan}^{1}$, Wei $\mathrm{Li}^{1}$, Junhong Guo ${ }^{1}$, Zhuo Chen ${ }^{1}$, and Hui Qin ${ }^{1}$ \\ ${ }^{1}$ North China Electric Power University
}

July 27, 2021

\begin{abstract}
Owing to the rich water resources, the Dadu River basin is an important hydroelectric resources development area in Sichuan Province over China. The climate change will have a great impact on the runoff change in the Dadu River Basin. The prediction of the future runoff in the Dadu River Basin can effectively improve the utilization rate of water resources, and provide a reference for hydropower dispatching. At first, to reduce the uncertainties from climate model, this paper used Stepwise Clustering Analysis to calibrate and validate the CORDEX regional climate model ensemble data from 1970 to 2005 and projected the climate change trend of Dadu River basin from 2035 to 2065. Then the Dadu River watershed scales of SWAT model was established, using the SWAT-CUP for calibration and verification. Finally, the corrected future climate data are used to drive the SWAT model to realize the future runoff forecast in the Dadu River Basin. The results show that under the scenario of RCP4.5 and RCP8.5, the variation range of rainfall is small, and the maximum and minimum temperatures show an overall increasing trend. The maximum (minimum) temperature will increase about 0.6 (1.0) under the scenarios of RCP4.5 and 0.9 (1.4) under the scenario of RCP8.5. Compared with the baseline period, the future (2035-2065) annual runoff under RCP4.5 and RCP8.5 scenarios will increase by about $8.6 \%$ and $8.2 \%$, respectively. Under the future climate change, the inter-annual runoff in the Dadu River Basin will change greatly, and the trend of runoff fluctuation is not consistent before and after 2050. Before 2050, runoff changes are small, however, after 2050, runoff changes under the two scenarios will increase by about $12 \%$. On the one hand, this trend may be due to the impact of iceberg melting on runoff caused by temperature changes around 2050, on the other hand, it may be due to the combined effect of local plant evapotranspiration and ecological regulation.
\end{abstract}

\begin{abstract}
Owing to the rich water resources, the Dadu River basin is an important hydroelectric resources development area in Sichuan Province over China. The climate change will have a great impact on the runoff change in the Dadu River Basin. The prediction of the future runoff in the Dadu River Basin can effectively improve the utilization rate of water resources, and provide a reference for hydropower dispatching. At first, to reduce the uncertainties from climate model, this paper used Stepwise Clustering Analysis to calibrate and validate the CORDEX regional climate model ensemble data from 1970 to 2005 and projected the climate change trend of Dadu River basin from 2035 to 2065. Then the Dadu River watershed scales of SWAT model was established, using the SWAT-CUP for calibration and verification. Finally, the corrected future climate data are used to drive the SWAT model to realize the future runoff forecast in the Dadu River Basin. The results show that under the scenario of RCP4.5 and RCP8.5, the variation range of rainfall is small, and the maximum and minimum temperatures show an overall increasing trend. The maximum (minimum) temperature will increase about 0.6 (1.0) under the scenarios of RCP4.5 and 0.9 (1.4) under the scenario of RCP8.5. Compared with the baseline period, the future (2035-2065) annual runoff under RCP4.5 and RCP8.5 scenarios will increase by about $8.6 \%$ and $8.2 \%$, respectively. Under the future climate change, the inter-annual runoff in the Dadu River Basin will change greatly, and the trend of runoff fluctuation is not
\end{abstract}


consistent before and after 2050. Before 2050, runoff changes are small, however, after 2050, runoff changes under the two scenarios will increase by about $12 \%$. On the one hand, this trend may be due to the impact of iceberg melting on runoff caused by temperature changes around 2050, on the other hand, it may be due to the combined effect of local plant evapotranspiration and ecological regulation.

\section{Hosted file}

manuscript . docx available at https ://authorea. com/users/427706/articles/531851-evaluation-ofthe-impacts-of-climate-change-on-runoff-in-dadu-river-basin-based-on-cordex-regionalclimate-model

(a)

(c)

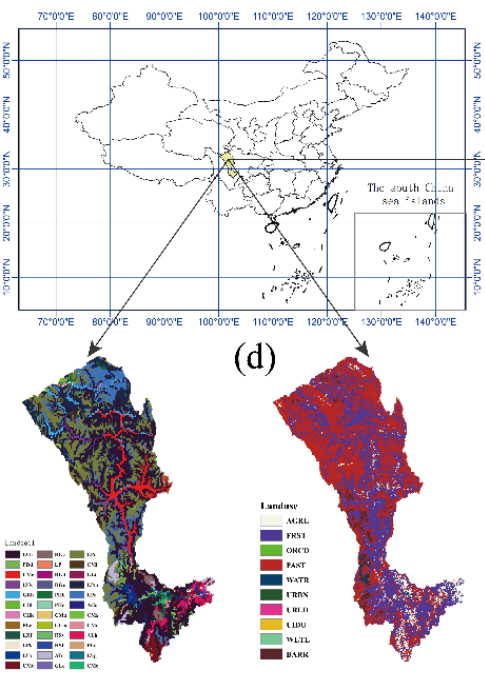

(b)

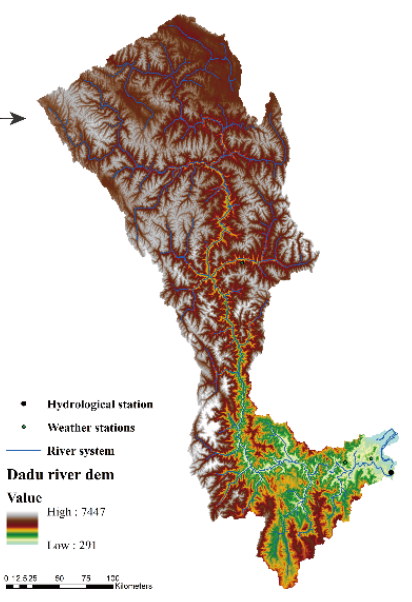

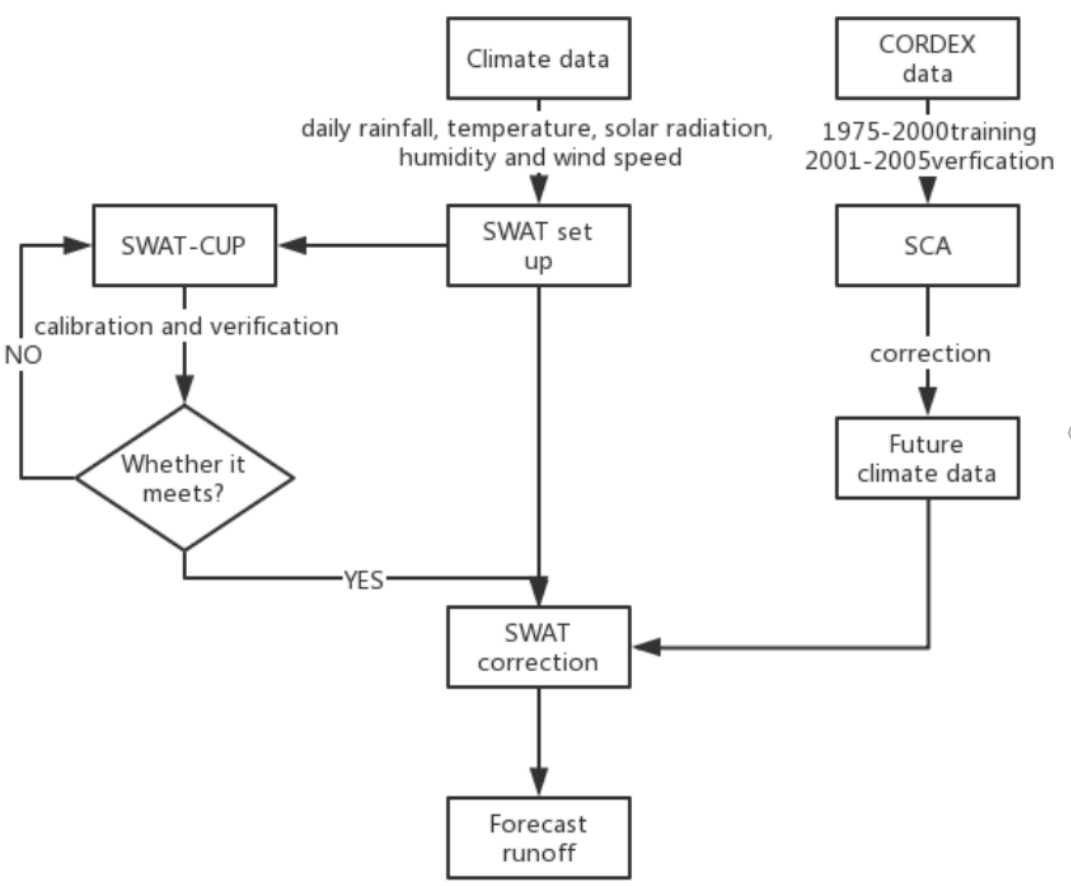



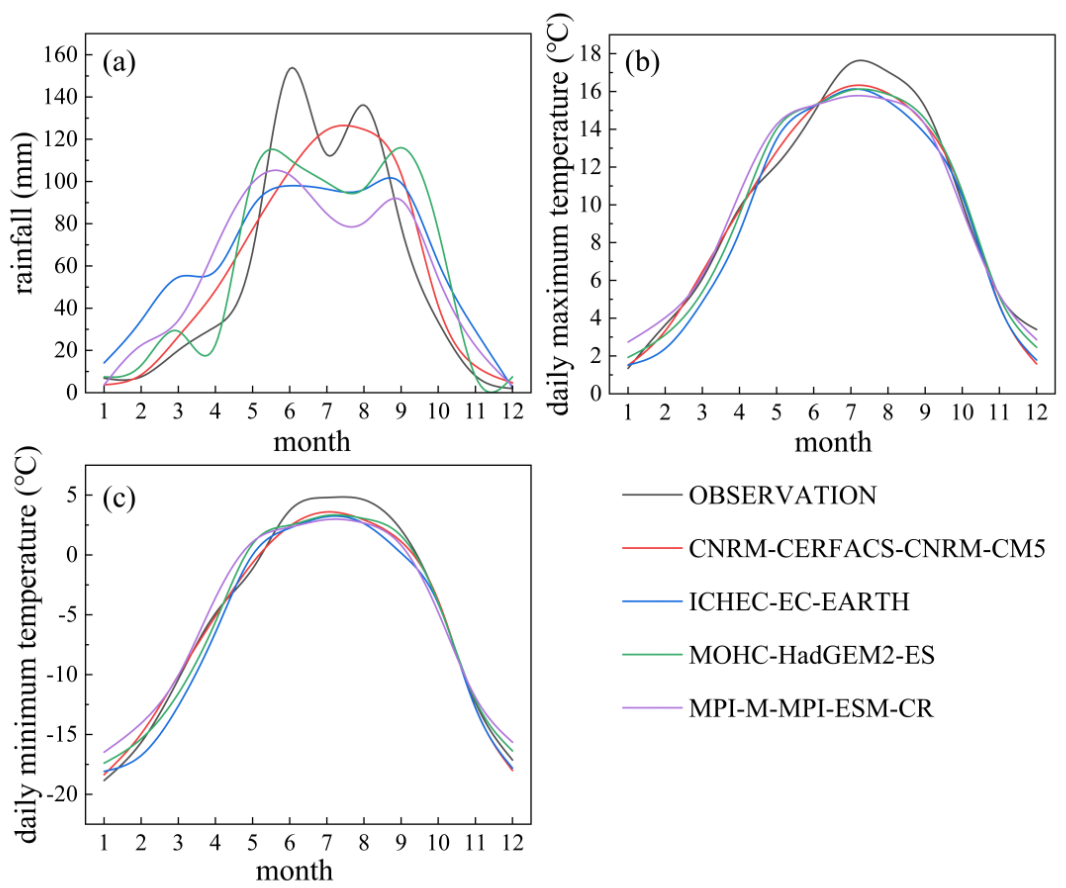

- OBSERVATION

CNRM-CERFACS-CNRM-CM5

_ ICHEC-EC-EARTH

- MOHC-HadGEM2-ES

MPI-M-MPI-ESM-CR
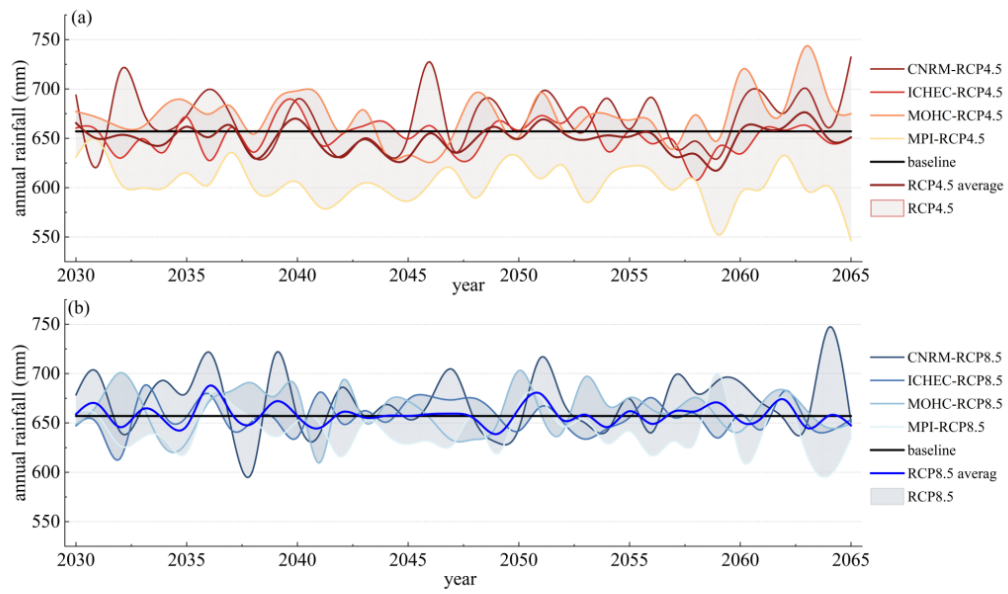

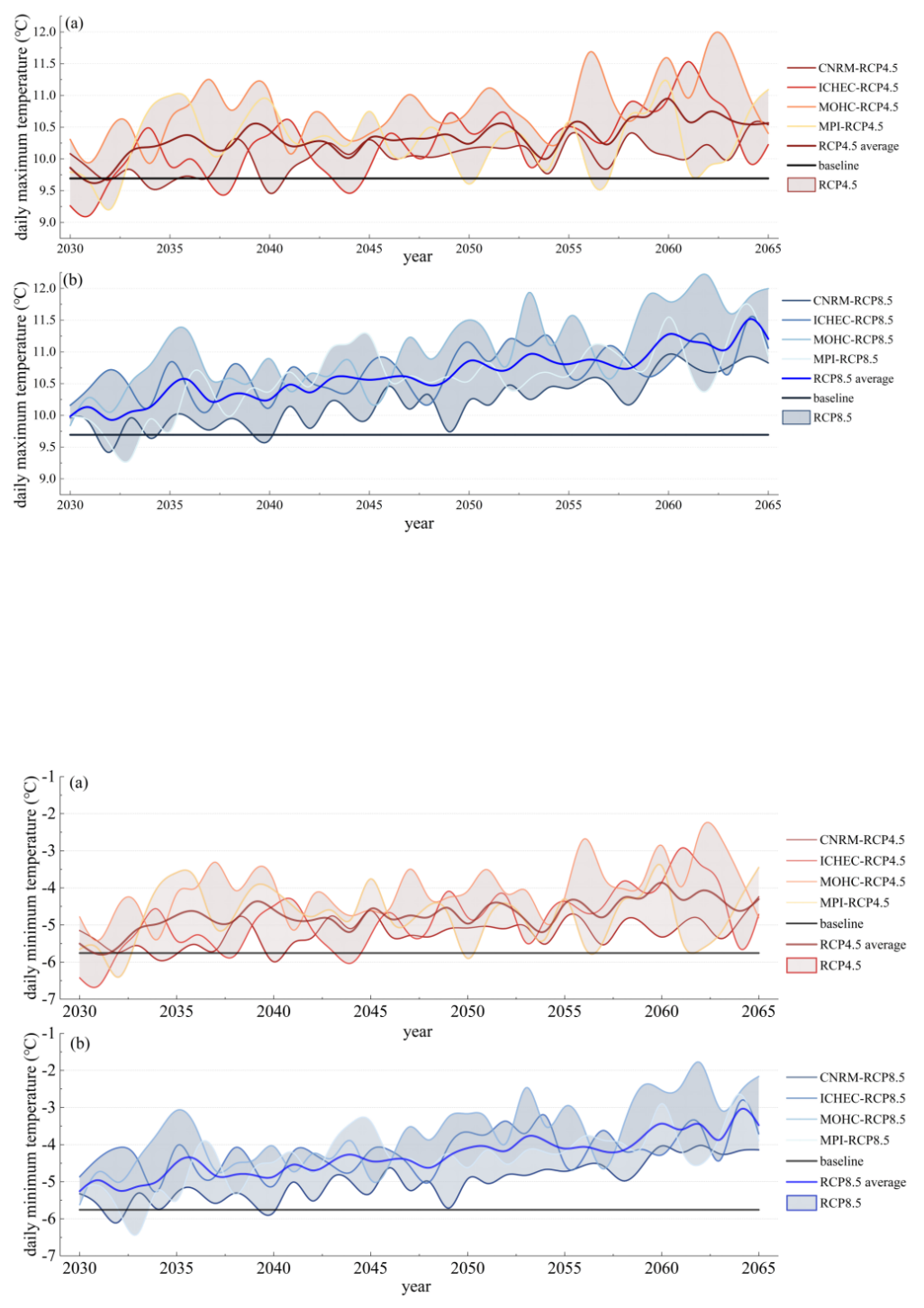

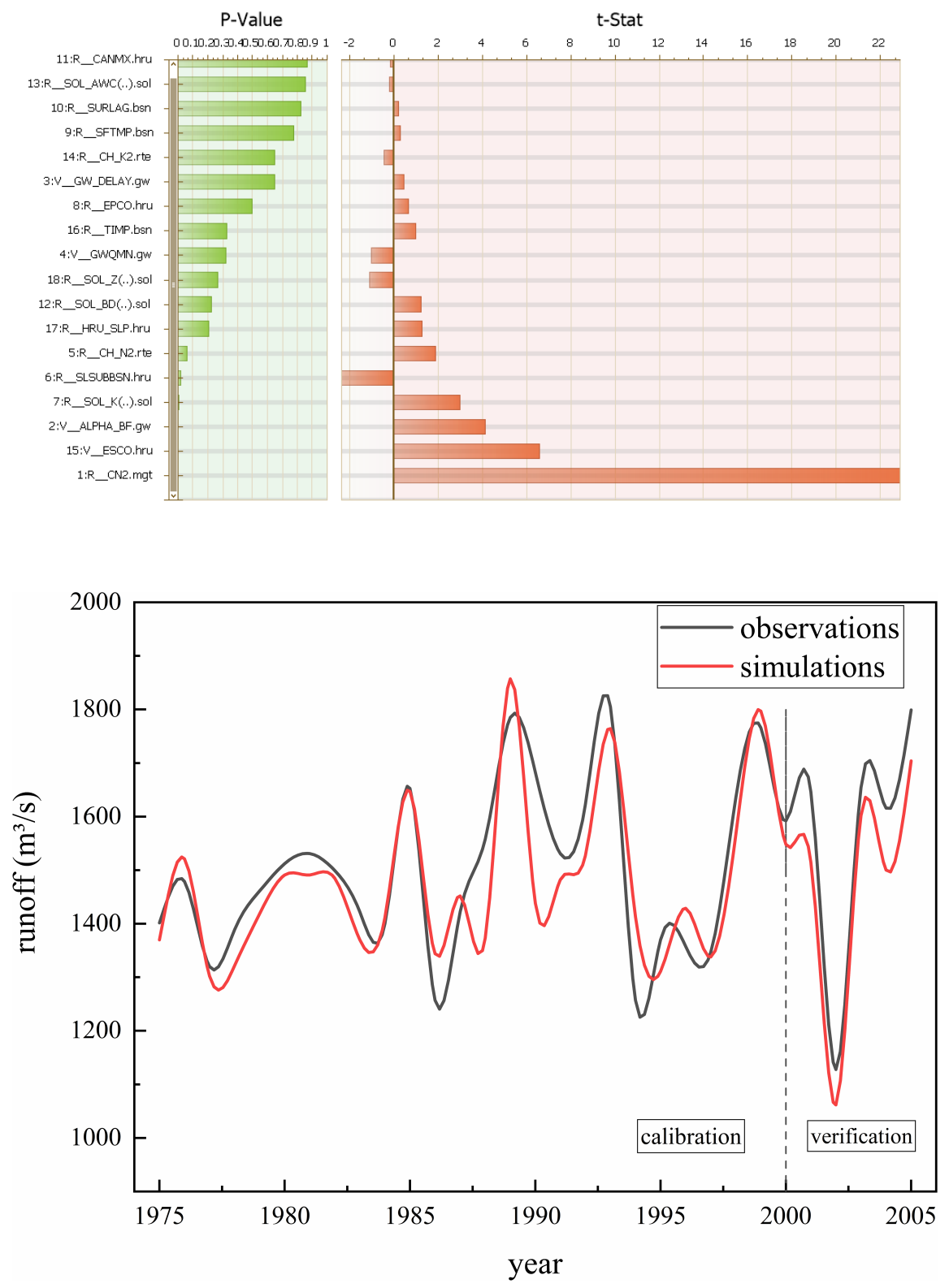


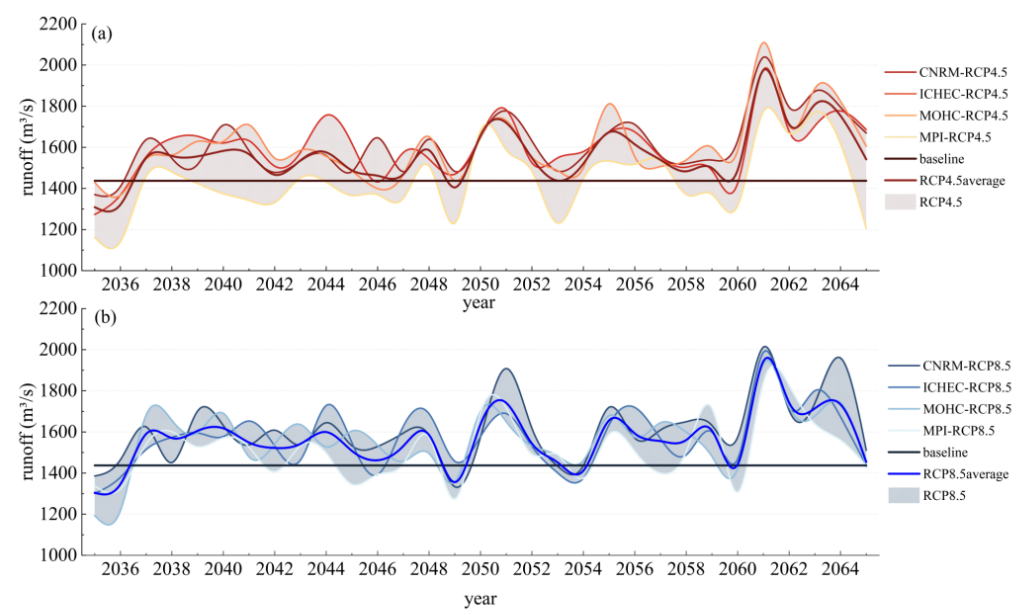

\section{Hosted file}

Table 1 CORDEX dataset.docx available at https://authorea.com/users/427706/articles/531851evaluation-of-the-impacts-of-climate-change-on-runoff-in-dadu-river-basin-based-oncordex-regional-climate-model

\section{Hosted file}

Table 2 Error analysis of annual mean total rainfall.docx available at https://authorea.com/ users/427706/articles/531851-evaluation-of-the-impacts-of-climate-change-on-runoff-indadu-river-basin-based-on-cordex-regional-climate-model

\section{Hosted file}

Table 3 Results of sensitivity analysis of model parameters.docx available at https: //authorea.com/users/427706/articles/531851-evaluation-of-the-impacts-of-climate-changeon-runoff-in-dadu-river-basin-based-on-cordex-regional-climate-model

\section{Hosted file}

Table 4 Annual runoff simulation evaluation of Tongjiezi hydrological station in Dadu River.docx available at https://authorea.com/users/427706/articles/531851-evaluation-of-the-impactsof-climate-change-on-runoff-in-dadu-river-basin-based-on-cordex-regional-climate-model

\section{Hosted file}

Table 5 Future climate conditions and runoff variation.docx available at https://authorea. com/users/427706/articles/531851-evaluation-of-the-impacts-of-climate-change-on-runoffin-dadu-river-basin-based-on-cordex-regional-climate-model 